\title{
A TÖBBSZINTÜ EGYETEMI KORMÁNYZÁS MINDENNAPI VALÓSÁGA
}

\author{
KASZA GEORGINA
}

ELTE Neveléstudományi Doktori Iskola

Jetta Frost, Fabian Hattke \& Markus Reihlen (eds): Multi-Level Governance in Universities: Strategy, Structure, Control. Springer, 2016. Cham xi +256 p.

ISBN 978-3-319-32678-8 (eBook)

A változó gazdasági, társadalmi környezetben az egyetem szerepe az elmúlt évtizedekben jelentősen átalakult, ami kihatott az állam, az egyetem és a piac közötti kapcsolatokra is. Az egyetemek irányítása is megváltozott, és egyre komplexebbé lett. A Springer Kiadó Multi-level Governance in Universities: Strategy, Structure, Control c. tanulmánykötete a Higher Education Dynamics c. sorozat részeként 2016-ban jelent meg, és 14 tanulmányt tartalmaz. A szerkesztőkön kívül 17 kutató kutatási eredménye jelenik meg a kötetben, két tanulmányon kívül mindegyik tanulmány több szerző írása. A bevezető és a záró, összefoglaló tanulmányok mellett a címben is megjelenő három tématerület (stratégia, struktúra és kontroll) mentén kilenc elemző tanulmányt olvashatunk. A tanulmányok korábbi empirikus és elméleti kutatásokon alapulnak, a kutatók törekedtek átfogó, elemző publikációk megírására. A tanulmányok nagy része az európai (nyugati) egyetemi világra fókuszál, a szerzők kutatói háttere miatt azonban nagyobb hangsúly került a német egyetemi változásokra, folyamatokra. A kutatók eltérő tudományos háttere a kötet olvasása során is jól kitűnik: a szervezetelméleti megközelítés mellett a menedzsment, oktatás- és tudománypolitikai megközelítések adják a tanulmányok fó elméleti kereteit.
A bevezető tanulmány a kötet elméleti, koncepcionális hátterét és a tanulmányok rövid ismertetését tartalmazza. A kötet abból a folyamatból indul ki, hogy az elmúlt évtizedek változásai az egyetemek kormányzását (governance) is átalakították. A tanulmányok pedig ezt a változást, az egyetemek irányításával, kormányzásával kapcsolatos folyamatokat, azok mechanizmusait, logikáját helyezik a fókuszba. A szervezetelméleti megközelítés mellett felsőoktatás-kutatási, történeti és szociológiai szempontból elemzik a szerzők a különböző szintű változásokat. A tanulmányok szerkesztésének koncepcionális keretét a kormányzási logika (governance logics) megközelítés jelenti. A kormányzási logika keretében - Jetta Frost, a könyv egyik szerkesztőjének és társainak korábbi munkáját alapul véve - a célok kijelölése (intézményen belül vagy kívül), valamint az érdekelt csoport összetétele (homogén, illetve heterogén) mentén négy fó kormányzási logikát különböztetnek meg a szerzők: önigazgatási (self-governance), új közmenedzsment (New Public Management) megközelítésű, közösségalapú (community-based governance), illetve piaci szemléletű kormányzás (market governance).

A többszintű kormányzás változása, szerepe a felsőoktatás-kutatási témák kö- 
zött egyre hangsúlyosabban jelenik meg. A kötet egyes tématerületei a makro-, mezo- és mikroszintű kormányzási szinteket vizsgálják, elemzik. Az első tematikus fejezet (Stratégia) a makroszintü kormányzásra fókuszál, és azt a kérdést járja körül, hogy az egyetemek hogyan, milyen mechanizmusokon keresztül ágyazódnak be a makroszintü folyamatokba, hogyan reagálnak a szervezeti környezetben végbemenő változásokra (például a felsőoktatás tömegesedésére, a hallgatói mobilitás élénkülésére, valamint a versenyen alapuló finanszírozásra), hogyan kezelik, használják a szellemi, szimbolikus és pénzügyi erőforrásaikat. A fejezet Markus Reiblen és Ferdinand Wenzlaff tanulmányával kezdődik. A szerzők célja annak a feltárása volt, hogy a felsőoktatási rendszer hogyan vált egy folyamatosan változó, alakuló rendszerré a nyugati országokban. $\mathrm{A} z$ institucionalista elméleti megközelítést alkalmazva hat történeti szakaszon keresztül mutatják be a német felsőoktatás történetét, alapvető változásait a második világháború utáni időszaktól kezdve a legutóbbi időkig. A tanulmány célja a társadalmi és kormányzási kérdések, makroszintü változások jobb megértése, valamint az ún. menedzselt oktatás (managed education) korszakába történő átmenet elemzése. A szerzők szerint ez utóbbi korszak egyik jelképe a vállalkozói egyetem. A tanulmány a menedzselt oktatás kormányzásának lehetőségeit és korlátait tárgyaló reflexióval zárul.

Mark Kwiek tanulmánya a vállalkozó egyetemi közösség (academic entrepreneurialism), a vállalkozó egyetem területén összegzi az elméleti és az empirikus kutatások eredményeit, és az egyetemi kormányzás és irányítás változását mutatja be több európai (pl. holland, egyesült királyságbeli) esettanulmányon keresztül. A vállalkozó egyetem számos országban ismert, egyes elemei egyre elterjedtebbé válnak. $\mathrm{A} z$ intézmények konvergenciája azt jelzi, hogy az egyetem mint kiváltságos intézmény egyre inkább elveszti korábbi pozícióját, szerepét a modern világban.

Mats Alvesson és Mats Benner azt a kritikai kérdést teszi fel, hogy a tudástársadalomban hogyan ítélhető meg a felsőoktatás tömegesedése, hogyan tekinthetünk a felsőoktatás szerepére. A szerzők az oktatás és a kutatás hasznosságát szem előtt tartva elemzik a tudás fogalmát, értelmezik a változó akadémiai vezetés szerepét. $\mathrm{A}$ tanulmány javaslatokkal zárul arra vonatkozóan, hogy az egyetem hogyan tud megfelelő képzést nyújtani, megfelelő minőséget fenntartani, és ezzel kapcsolatosan hogyan lehet újraéleszteni az akadémiai értékeket az egyetemi kormányzás területén.

A tanulmánykötet második tématerülete (ez a Struktúra c. rész) a mezoszintü struktúrákkal és folyamatokkal foglalkozik, és arra a kérdésre keresi a választ, hogy az egyetemek hogyan szabályozzák a különböző folyamatok szervezését a stratégiai változás és együttmüködés erősítése érdekében. E tématerület fókusza a szervezeti szintü folyamatokon, azok egyetemek általi értelmezésén, lefordításán van. Marie Boitier és Anne Rivière tanulmánya a menedzsment professzionalizálódására fókuszál. Az ún. „harmadik tér szakembereinek” („third space professionals”) megjelenése szorosan összefügg az egyetemek adminisztratív folyamatainak professzionalizálódásával. A szerzők az új intézményelmélet keretében elemzik, hogy az új menedzsment intézményi logika hogyan hatott az egyetemek különböző munkatársainak professzionalizálódására. A kutatók 2007 és 2012 között készítettek longitudinális kvalitatív esettanulmányt egy francia egyetemen, részletes interjúk és életrajzi adatok gyüjtése alapján. Az eredmények azt mutatják, hogy az egyetemen belül az új menedzsment intézményi logika, a professzionalizálódási 
folyamat valamennyi szakmai csoportot legalább részben érinti, a különböző szakmai csoportok közötti kölcsönhatás pedig erőteljesen segíti ezt a folyamatot.

Fabian Hattke, Steffen Blaschke és Jetta Frost szervezetelméleti keretrendszerben vizsgálja az önkéntes kollektív fellépés, a szervezett együttmüködés és a közjavak közötti kapcsolatot. A szerzők azt elemezték, hogy a speciális központi támogatási struktúrák hozzájárulnak-e a teljesítményhez az alábbi három cselekvési területen: fiatal kutatók képzése, nemzetköziesítés, nemek közötti sokszínűség. A szerzők azt a következtetést vonták le, hogy az önkéntes kollektív fellépés és a szervezett együttmüködés az egyes cselekvési területeken más-más teljesítményt mutat. A kvantitatív kutatási eredmények arra utalnak, hogy a szervezett együttmüködés a fiatal tudósok és a nemek közötti sokszínüség területén vezethet jobb teljesítményhez. Ugyanakkor az önkéntes kollektív fellépés erősíti a nemzetközivé válást. A tanulmány visszajelzést ad a szervezeti múködés hatékonyságáról a felsőoktatás-kutatás és a szakpolitika részére.

J.-C. Spender azt a kérdést vizsgálja, hogy hogyan értelmezhető a tudás, mi teszi nehézkessé az egyetemi kormányzást. Elemzése szerint az egyetemi adminisztráció problémái az egyes tudományágakra jellemző tudás természetében gyökereznek. A szerző elméleti kutatásokra hivatkozva amellett érvel, hogy az egységes logika nem alkalmazható olyan egyetemeken, ahol eltérő tudományágak (pl. természettudományok és humán tudományok) együttesen vannak jelen. A kormányzási problémák természetének megértéséhez azt javasolja, hogy először azonosítsák a különféle tudományok céljait. Példaként véve az üzleti tudományágat, annak történetét vizsgálva, azt a következtetést vonja le, hogy az egyetem mint vállalkozás és az egyetem mint intézmény közötti feszültség már régóta fennáll.

Az új közmenedzsment a felsőoktatás irányításának egyik legfontosabb tendenciájává vált az elmúlt két évtizedben. A felsőoktatásban való megjelenése azt eredményezte, hogy az intézmények nagyobb hangsúlyt helyeznek a teljesítményértékelésre, alkalmazásával az intézmények arra törekednek, hogy növeljék, biztosítsák az oktatók megfelelő teljesítményét. A tanulmánykötet harmadik témaköre a mikroszintű folyamatok keretében azt a kérdést vizsgálja, hogy a teljesítménymenedzsment és a kimenetalapú értékelés mennyire befolyásolja a munkahelyi viselkedést, hogyan alakítja az oktatói és vezetői gyakorlatot. A kutatás és az oktatás alapvető tudományos tevékenységek, amelyek mindig is érintettek voltak a különböző ellenőrzési, minősítési gyakorlatokban, ugyanakkor az elszámoltathatóság iránti növekvő igény miatt a teljesítményintézkedéseknek ezzel kapcsolatos különböző új formái jöttek létre, mint például minősítések, rangsorok, kutatási értékelési gyakorlatok, akkreditációk.

Julia Weiherl és Jetta Frost tanulmánya egy németországi, üzleti tudományok területén dolgozó oktatókat elemző esettanulmányon alapul. A szerzők azt vizsgálták, hogy a kimenetalapú teljesítménymenedzsment hogyan befolyásolja az oktatók, kutatók viselkedését, hogyan vezethet nem kívánt viselkedéshez. A szerzők amellett érvelnek, hogy az ítélkező teljesítményértékelés a szervezeti elkötelezettség elvesztését eredményezheti, oktatók, kutatók esetében pedig konfliktushelyzetet teremt a szervezeti és szakmai elkötelezettség között. Az oktatók, kutatók jobban elkötelezettek szakmájuk, tudományuk, tudóstársaik iránt, mint a szervezet felé. A tanulmány következtetése szerint a fejlesztést célzó teljesítménymenedzsment alkalmazása segíti a szakmai és szervezeti 
elkötelezettség összehangolását, javítja az egyén elköteleződését a szervezet iránt. Egy rugalmas, kölcsönösen elfogadott értékeken alapuló teljesítményelvek mentén történő értékelés jobban igazodik a kutató, oktató közösséghez.

Stefanie Ringelhan, Jutta Stumpf-Wollersheim és Isabell Welpe azt a kérdést vizsgálták, hogy hogyan lehetne javítani az oktatók, kutatók egyéni, munka iránti motivációján és munkateljesítményén. A szerzők németországi egyetemeken készítettek narratív interjúkat különböző pozíciókban dolgozó oktatókkal, kutatókkal. Az elemzésük azt mutatja, hogy a jó vezetési stílus és az interperszonális elismerés motiválhatja az egyént, a megfelelő szervezeti struktúra és vezetői kultúra ugyancsak elősegíthetik a motiváció és a teljesítmény javulását.

Isabel Bögner, Jessica Petersen és Alfred Kieser azt a kritikai kérdést teszi fel (már tanulmányuk címében is), hogy lehetséges-e a tudományos fejlődés értékelése teljesítménymutatókkal. Amellett érvelnek, hogy az idézettségen alapuló rangsorok nem tudják visszaadni a tudomány komplexitását - az összehasonlíthatóság, az objektivitás és a kvantifikálhatóság érdekében egyszerüsített tudományképet mutatnak meg. A rangsorok inkább akadályozzák a tudományos előrehaladást, mint elöreviszik azt. A tanulmány kifejti, hogy a tudományágak és altudományok létrehozása hogyan jelzi a tudományos fejlődést. Az elméleti kutatáson alapuló elemzés azt is tárgyalja, hogy mi lehet az új tudományok sikeres fejlesztésének, fejlődésének előfeltétele, útja. A szerzők szerint az ún. láthatatlan kollégiumok (invisible colleges) létrehozása lehet az egyik kiindulópontja a tudományos fejlődésnek. A szerzők arra a következtetésre jutottak, hogy annak értékelése, hogy egy intézmény milyen mértékben járul hozzá a tudományos fejlődéshez, végső soron egy kvalitatív (nem pedig kvantitatív) gyakorlat.

A tanulmánykötet kitekintő zárótanulmánya Fabian Hattke, Rick Vogel és Hendrik Woiwode munkája. A szerzők azt a kérdéskört vizsgálják, hogy mi történik akkor, amikor szakmai és szervezeti logikák ütköznek, valamint azt, hogy milyen intézményi logikák és ellenőrzési módok határozzák meg az ún. láthatatlan és látható kollégiumok működését. A tanulmány a neoinstitucionalista szervezetelmélet keretében vizsgálja az intézményi komplexitás következményeként kialakuló innovációs dilemmákat, az identitáskonfliktusokat, valamint a szerepekkel járó küzdelmeket, amelyek különböző ellenőrzési módokat, logikákat alakítanak ki. A szervezet és az egyének eltérő módon válaszolnak ezekre a feszültségekre. A szerzők a látható és láthatatlan kollégiumok további elemzését tartják szükségszerűnek.

A könyv nemcsak a felsőoktatás-kutatók, hanem a felsőoktatás további érdekelt szereplöi számára is érdekes és fontos olvasmány. A tanulmánykötet értéke a kormányzási folyamatok általi kihívások és megoldások elemző feltárásában, a szervezetelméleti megközelítések alapos alkalmazásában, valamint a módszertani háttér sokféleségében rejlik.

A cikk a Creative Commons Attribution 4.0 International License (https://creativecommons.org/licenses/ by-nc/4.0/) feltételei szerint publikált Open Access közlemény, melynek szellemében a cikk bármilyen médiumban szabadon felhasználható, megosztható és újraközölhető, feltéve, hogy az eredeti szerző és a közlés helye, illetve a CC License linkje és az esetlegesen végrehajtott módosítások feltüntetésre kerülnek. 